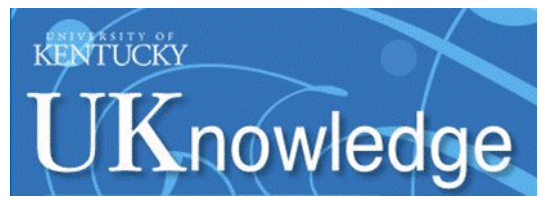

University of Kentucky

UKnowledge

Biosystems and Agricultural Engineering Faculty Publications

\title{
Evaluation of Chemical Additives for the Separation and Recovery of Bacteria from Food Matrices
}

\author{
Jennifer Leanne Frederick \\ University of Kentucky, jlfred2@uky.edu \\ Stephen P. Walker \\ University of Kentucky, stephenpwalker@uky.edu \\ Czarena L. Crofcheck \\ University of Kentucky, crofcheck@uky.edu \\ Melissa Newman \\ University of Kentucky, mnewman@uky.edu \\ Frederick Payne \\ University of Kentucky, fred.payne@uky.edu
}

Follow this and additional works at: https://uknowledge.uky.edu/bae_facpub

Part of the Bioresource and Agricultural Engineering Commons

Right click to open a feedback form in a new tab to let us know how this document benefits you.

\section{Repository Citation}

Frederick, Jennifer Leanne; Walker, Stephen P.; Crofcheck, Czarena L.; Newman, Melissa; and Payne, Frederick, "Evaluation of Chemical Additives for the Separation and Recovery of Bacteria from Food Matrices" (2013). Biosystems and Agricultural Engineering Faculty Publications. 5.

https://uknowledge.uky.edu/bae_facpub/5

This Article is brought to you for free and open access by the Biosystems and Agricultural Engineering at UKnowledge. It has been accepted for inclusion in Biosystems and Agricultural Engineering Faculty Publications by an authorized administrator of UKnowledge. For more information, please contact UKnowledge@lsv.uky.edu. 


\section{Evaluation of Chemical Additives for the Separation and Recovery of Bacteria from Food Matrices}

\section{Digital Object Identifier (DOI)}

http://dx.doi.org/10.13031/bet.6.10084

\section{Notes/Citation Information}

Published in Biological Engineering Transactions, v. 6, no. 2, p. 105-115.

Copyright 2013 American Society of Agricultural and Biological Engineers.

The copyright holder has granted permission for posting the article here. 


\title{
Evaluation of Chemical Additives for the Separation and Recovery of Bacteria from Food Matrices
}

\author{
J. L. Frederick, S. P. Walker, C. Crofcheck, M. Newman, F. Payne
}

\begin{abstract}
The microbiological testing of foods is a well-established science. Due to the severity of foodborne pathogen illnesses, the widespread use and implementation of rapid detection methods in food testing labs is increasingly important. The first step for successful testing is sampling. Surfactants have been widely used in food microbiology, but there is not much, if any, published research about the use of fatty alcohols and chemical dispersants as aids in microbial separation and recovery. The microbial extraction efficiency of Escherichia coli K12 and Listeria innocua from three representative food matrices (hot dogs, spinach, and milk) was measured using chemical additives (surfactants, fatty alcohols, and a chemical dispersant) at three concentrations, each in a buffered solution. The food matrices were inoculated with a known amount of bacteria, blended in a buffer solution, with and without additives, and then centrifuged. Data were analyzed through selective media plate counts. Results showed that Tween 80 at $0.01 \%$ was found to be the most effective additive for microbial recovery from each food matrix examined. However, the addition of fatty alcohols to surfactants significantly aided in separation and recovery, and should be further studied.
\end{abstract}

Keywords. Chemical dispersant, Fatty alcohol, Foodborne pathogen, Food sampling, Surfactant.

$\mathrm{T}$ The analysis of foods for the presence of foodborne pathogens is a standard practice to ensure the safety of food for human consumption. However, the composition of food matrices can make the analysis complicated. Foods contain a wide range of ingredients, which include proteins, carbohydrates, fats, oils, and other chemicals (Swaminathan, 1994). Some of these can have adverse effects on the viability of bacteria and can interfere with pathogen detection. Differences in solid versus semi-solid versus liquid foods also pose challenges. The presence of fats and oils with different viscosities creates difficulties in obtaining consistent results. In addition, the presence of indigenous microflora poses challenges in the detection of pathogens that may be present in very small quantities. Finally, food processing techniques such as high-pressure processing, freezing, drying, introducing preservatives, and other chemicals can sublethally injure pathogens, causing them to be sensitive to growth media and possibly not be detectable

Submitted for review in December 2012 as manuscript number BET 10084; approved for publication by the Biological Engineering Division of ASABE in May 2013.

The authors are Jennifer L. Frederick, ASABE Member, Graduate Student, Stephen P. Walker, ASABE Member, Assistant Research Professor, and Czarena Crofcheck, ASABE Member, Associate Professor, Department of Biosystems and Agricultural Engineering; Melissa Newman, Associate Professor, Department of Food and Animal Sciences; and Frederick Payne, ASABE Fellow, Professor Emeritus, Department of Biosystems and Agricultural Engineering, University of Kentucky, Lexington, Kentucky. Corresponding author: Czarena Crofcheck, 128 C.E. Barnhart Bldg. University of Kentucky, Lexington, KY 40546; phone: 859-257-3000; e-mail: Crofcheck@uky.edu. 
using traditional methods for foodborne pathogen testing, even though they may still be a threat in the food (Yuste et al., 2004). There is a great need for improved methods for foodborne pathogen detection in food matrices.

Because of the increasing risks of foodborne illnesses, there has been much research on improving microbiological methods to detect foodborne pathogens. Due to advances in molecular microbiology, scientists are discovering ways to distinguish one microorganism from another based on metabolic traits, nucleic acid sequences, or structural components, among others (Brehm-Stecher et al., 2009). However, many times these detection methods neglect to include the initial preparation step of the food sample. Instead, they focus more on clinical samples, which are typically much more homogeneous than food samples. It is difficult to apply novel detection methods to food matrices without an adequate protocol to properly prepare the sample to be tested.

There must be a way to prepare a food sample such that it can be successfully incorporated into the novel assays for detection and identification of pathogens. To do this, various criteria should be kept in mind to produce a homogeneous sample: separate target cells from food, increase their concentration while reducing the volume of sample, remove any extraneous material, and exclude inhibitory substances for further downstream processing and identification (Mandal et al., 2010).

Developing a general protocol to separate and purify target cells from different food matrices is extremely difficult to achieve because food matrices vary greatly in composition from one to another (e.g., tomatoes vs. peanut butter). Microbiological analysis of food must be able to detect small numbers of bacteria in different types of complex samples. The primary goal of this research was to test certain chemical additives for their ability to aid the separation of microorganisms from food samples.

Chemical methods to separate bacteria from food matrices involve altering the chemistry of certain components of the homogenized samples. Desorption, also known as elution, is one such method that is the process of detaching adsorbed substances from the surface of a solid matrix. Some of the physiochemical interactions to do this include van der Waal's forces, electrostatic interactions, hydrophobic interactions, and hydrogen bonding (Stevens and Jaykus, 2004). Cell wall components, such as teichoic acids and proteins, influence bacterial attachment to food surfaces (Butler et al., 1979). By altering the physiochemical interactions, desorption can occur due to disruption of chemical forces. Payne and Kroll (1991) concluded that differences in bacterial cell wall composition could help in the development of separation methods based on differential adsorption and desorption.

Various chemical compounds have been used in food microbiology to separate bacteria from foods. It was the goal of this research to examine more closely the use of commonly used chemical additives as well as others that have not been used before, and to compare their efficacy at separating microbes from different foods. In order to measure the success of a separation method, the recovery of organisms must be easily quantified. The aim of this study was to keep the microorganisms alive through the various treatments so that the separation could be quantified.

Tween 20, Tween 80, Brij 35, and Tergitol NP 40 are all non-ionic surfactants. Surfactant molecules are of interest in bacterial separation because they have hydrophilic and hydrophobic regions that orient to surfaces in such a way that modifies hydrophobic surfaces to become more hydrophilic (Hill et al., 2005). Surfactants have been used in microbial laboratory techniques previously where the goal was to minimize microbial adhesion to surfaces. 
Tween 20 is an emulsifier with the molecular formula $\mathrm{C}_{58} \mathrm{H}_{114} \mathrm{O}_{26}$ and is commonly used as a washing agent in immunoassays and in pharmaceutical applications to emulsify essential oils in distilled water. Miller et al. (2011) reported that the addition of Tween 20 to a saline buffer solution significantly increased Salmonella recovery from contaminated lettuce and tomatoes. Fukushima et al. (2007) added $0.02 \%$ Tween 20 to buffered peptone water (BPW) to emulsify fat in food samples as part of the sample preparation before homogenization.

Tween $80\left(\mathrm{C}_{64} \mathrm{H}_{124} \mathrm{O}_{26}\right)$ is an emulsifier that is a viscous, soluble yellow liquid commonly used in foods. Lukasik et al. (2001) found that in order to elute bacteria from the surface of seeded strawberries and tomatoes, it was necessary to disrupt the hydrophobic and electrostatic interactions between the bacteria and produce surface. The addition of $0.1 \%$ Tween 80 to phosphate-buffered saline (PBS) increased bacterial recovery an average of two-fold compared to PBS by itself.

Brij $35\left(\mathrm{C}_{58} \mathrm{H}_{118} \mathrm{O}_{24}\right)$ is used as a component of cell lysis buffers or as a surfactant in high-performance liquid chromatography (HPLC) applications. Brown and Jaffé (2001) showed that the use of Brij 35 enhanced the bacteria transport through a column of porous media. Garcia et al. (2001) showed that the presence of Brij 35 suppressed the contact of bacteria with a Teflon surface.

Nonyl phenoxypolyethoxylethanol (NP 40) is used in paper and textile processing, paints and coatings, and agrochemicals. It was used in addition to lactic acid as a disinfecting rinse for cantaloupe. The addition of NP 40 at $0.3 \%$ to a solution of lactic acid at $35^{\circ} \mathrm{C}$ was shown to enhance the removal of $E$. coli $0157: \mathrm{H} 7$ cells from the cantaloupe rind (Materon, 2003).

Fatty alcohols are aliphatic alcohols (non-aromatic) that consist of a chain of 8 to 22 carbon atoms. They are produced by bacteria, plants, and animals as a source of metabolic water and energy, and buoyancy in some cases (Mudge et al., 2010). These alcohols are used in the production of detergents and surfactants and are used as emulsifiers and thickeners in the cosmetics and food industry.

The molecular formula of the fatty alcohol 1-decanol is $\mathrm{C}_{10} \mathrm{H}_{21} \mathrm{OH}$. Hamilton-Kemp et al. (2005) showed that certain long-chain alcohols, including 1-decanol, are produced by enteric Gram-negative bacteria, including E. coli. Neumann et al. (2006) determined that cells of Pseudomonas putida that were grown in $10 \%$ (vol/vol) 1-decanol had enhanced cell hydrophobicity and more negative cell surface charges than cells grown without 1-decanol. However, the cells also had a $10 \%$ reduced growth rate and $48 \%$ reduced growth yield than cells grown without 1-decanol. While this study showed the ability of certain bacteria to adapt to the presence of this solvent, 1-decanol at high enough concentrations had a lethal effect on other bacteria. The molecular formula of the fatty alcohol 2-ethylhexanol is $\mathrm{C}_{8} \mathrm{H}_{17} \mathrm{OH}$. Neither of these compounds has been previously used for bacterial separation from foods, and both are economical and easily obtained alcohols.

Sodium polyphosphate (NaPP) compounds, a type of chemical dispersant, are highly negatively charged chemicals produced in various phosphate chain lengths. Sharma et al. (1985) showed that for two common species of bacteria (Bacillus subtilis and Pseudomonas fluorescens), the addition of NaPP to growth media drastically changed the extent of bacterial adhesion to soil samples. NaPP compounds work as dispersants by changing the surface charge of microbes, particles, and filter surfaces, and they significantly reduce the zeta potential of suspended microbes (Hill et al., 2005).

For this research, seven chemical additives were used in a buffer solution to test their 
efficiency at aiding in the separation and recovery of bacteria from foods: four surfactants (Tween 20, Tween 80, Brij 35, Tergitol NP 40), two fatty alcohols (hexanol and decanol), and one chemical dispersant (NaPP). Three concentrations were tested for each surfactant. The concentration levels for the surfactants and chemical dispersant were $0.01,0.1$, and $1(\mathrm{w} / \mathrm{w} \%)$ based on typical concentrations currently used in food microbiology. Due to the potential lethality of fatty alcohols to bacteria at $1 \%$, the concentrations tested were $0.001,0.01$, and 0.1 (w/w\%). Lastly, combinations of the additives with the highest recovery were tested to see if any improvements in recovery could be made.

\section{Materials and Methods}

\section{Bacteria}

Escherichia coli K12 (ATCC 11775) and Listeria innocua (ATCC 33091) were obtained from the Department of Animal and Food Sciences, University of Kentucky. Both bacteria were stored on a slant of brain heart infusion agar (BHIA; BD Diagnostics, Franklin Lakes, N.J.) and inoculated from the slant to a test tube of $9 \mathrm{~mL}$ brain heart infusion broth (BHI; BD Diagnostics) the day before experimentation with each food matrix commenced. For the remainder of experimentation, $1 \mathrm{~mL}$ (roughly $10^{8} \mathrm{CFU} \mathrm{mL}^{-1}$ ) of bacteria in broth was inoculated into $9 \mathrm{~mL}$ of fresh $\mathrm{BHI}$ and incubated for $18 \mathrm{~h}$ at $35^{\circ} \mathrm{C}$ for the next day's use. Each day, $2 \mathrm{~mL}$ each of E. coli and L. innocua in BHI were combined into one test tube and vortexed for $15 \mathrm{~s}$ before being further use. Plate counts were taken each day to determine the initial cell concentration of both bacteria.

\section{Materials}

Buffered peptone water (BPW; BD Diagnostics) was the buffer solution used for each of the food matrices. Surfactants used were: Tween 80 (VWR International, West Chester, Pa.), Tween 20 (Amresco, Solon, Ohio), Brij 35 (Alfa Aesar, Ward Hill, Mass.), and Tergitol NP-40 (Spectrum Chemical, Gardena, Cal.).

One chemical dispersant and two fatty alcohols were also tested: sodium polyphosphate (NaPP; Spectrum Chemical, Gardena, Cal.), 1-decanol (Alfa Aesar), and 2-ethyl-1-hexanol (Acros Organics, Pittsburgh, Pa.).

Surfactants, chemical dispersant, and fatty alcohols were added directly to BPW before being autoclaved at $121^{\circ} \mathrm{C}$ and $15 \mathrm{psi}$ for $20 \mathrm{~min}$. All media were made with deionized water and stored in a dry cabinet after being autoclaved.

Hot dogs (Oscar Mayer Naturals, Kraft Foods, Northfield, Ill.), fresh spinach, and whole milk were purchased from a local grocery store.

\section{Experimental Design}

A full factorial experimental design was implemented for three factors: food matrix, additive, and concentration. Seven additives at three concentrations each were used for each food matrix. Each food matrix had a total of 66 trials (three replications per additive/concentration combination) including a control where no additive was added to BPW. The order of trials was randomized such that no additive and concentration combination was tested more than once in each 22-trial block.

Once the data were analyzed, the additive/concentration combination that resulted in the highest separation/recovery for each food was further examined. The idea was to select an additive and concentration from each class of chemical additive (surfactants, 
fatty alcohol, chemical dispersant) and then see what, if any, impact the combination of additives would have on separation of each bacteria from the three foods. Another experiment was then conducted for each food matrix and had a total of 32 trials, which included four replications of each treatment (surfactant, fatty alcohol, chemical dispersant, surfactant + fatty alcohol, surfactant + chemical dispersant, fatty alcohol + chemical dispersant, all three combined, and control). Finally, two specific combinations of additives were examined more closely, and the experimental protocol was slightly altered (see Experimental Protocol below) so that all the samples came from the same batch of inoculated food, with the goal of enhancing the statistical significance of the results by minimizing variability in the inoculation levels. There were six treatments with three replications each.

\section{Enumeration}

For bacteria enumeration, decimal dilutions of the inoculum, food homogenate, or supernatant were prepared using peptone water $0.1 \%$ (PW; BD Diagnostics). A $1 \mathrm{~mL}$ sample from the food homogenate was pipetted into a test tube of $9 \mathrm{~mL} \mathrm{PW}$ to obtain a $10^{-1}$ dilution. Ten-fold serial dilutions were made up to $10^{-3}$. One $\mathrm{mL}$ samples of the $10^{-3}$ dilution were pipetted onto E. coli Petrifilm (3M, St. Paul, Minn.) or into petri dishes using the poured plate technique for Listeria counts using PALCAM agar (Oxoid Limited, Basingstoke, U.K.). After media solidified, plates were inverted and incubated along with Petrifilm for $24 \mathrm{~h}$ at $35^{\circ} \mathrm{C}$. Colony forming units (CFU) from agar plates and Petrifilm were manually counted and numbers recorded.

\section{Experimental Protocol}

Hot dog and spinach samples were weighed $(20 \pm 0.1 \mathrm{~g})$ and inoculated with $20 \mu \mathrm{L}$ of both $E$. coli and L. innocua in broth. The samples were allowed to sit for $5 \mathrm{~min}$ at room temperature before being further processed. BPW with the additive of the desired concentration, totaling a volume of $180 \mathrm{~mL}$, was placed in a laboratory blender (Waring, Torrington, Conn.) with the inoculated hot dog or spinach sample. Samples were blended at approximately 22,000 rpm for $2 \mathrm{~min}$. A $1 \mathrm{~mL}$ sample was then pipetted in selective media for a plate count. The sample in the blender was then subjected to a low-speed centrifugation (2000 rcf) for $3 \mathrm{~min}$. Another $1 \mathrm{~mL}$ of supernatant was plated for plate count. Twenty $\mathrm{mL}$ samples of milk were inoculated following the same procedure as the hot dog and spinach samples and then diluted with $30 \mathrm{~mL}$ BPW and shaken in an arc for 20 counts. After $5 \mathrm{~min}$ at room temperature, a plate count was taken, and the samples were centrifuged ( $2000 \mathrm{rcf}$ for $3 \mathrm{~min}$ ). A plate count was then taken of the supernatant.

For the final trials conducted to examine more closely the use of two additives, the protocol was slightly altered. The procedure followed can be seen in figure 1 . Tween 80 $(0.01 \%)$ and NaPP $(0.1 \%)$ were added to buffer solution for hot dogs, spinach, and milk samples. The other combination examined more closely was that of Tween $80(0.01 \%)$ and hexanol $(0.001 \%)$. Food samples were homogenized in buffer and then divided into six $50 \mathrm{~mL}$ sample containers. BPW was then added to the control samples, and the combination of two additives and BPW were added to the other samples to reach $50 \mathrm{~mL}$ with the proper concentration of additives. Each sample was blended again for $60 \mathrm{~s}$ before undergoing the low-speed centrifuge step, as outlined previously. After the supernatant was poured off, a plate count was taken. 


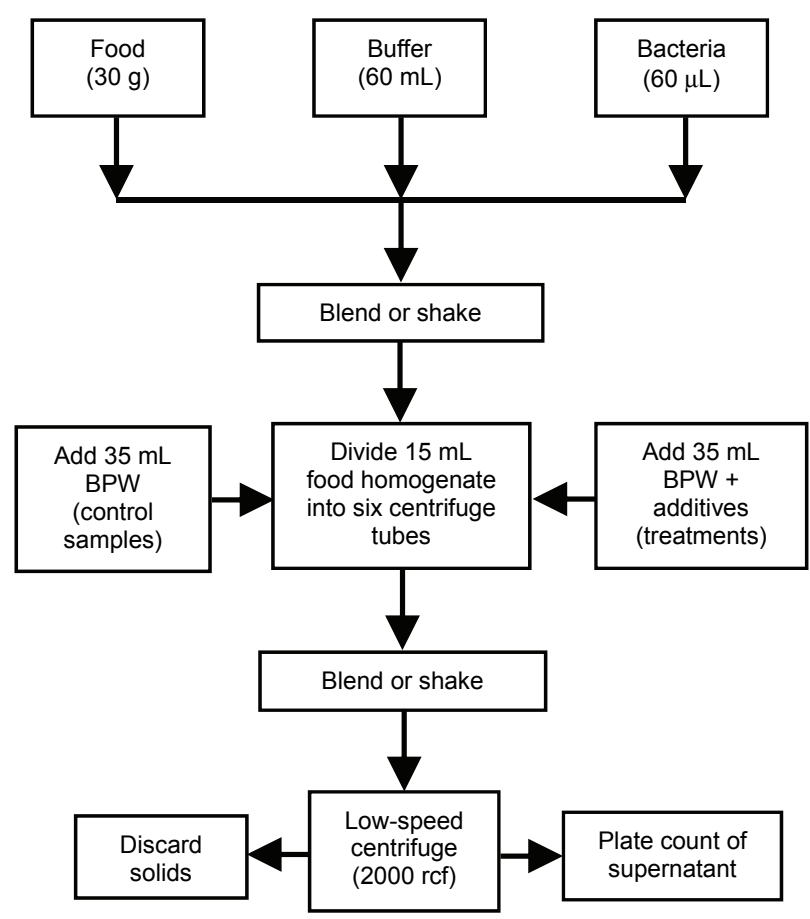

Figure 1. Procedure for additive combination experiments conducted in one day ( $n=6$ for each food).

\section{Results and Discussion}

A total of 198 experiments were conducted initially to determine which additive from each class (surfactant, fatty alcohol, chemical dispersant) provided the highest recovery of both E. coli and L. innocua from each food tested, and whether or not the concentration of the additive had an effect on recovery of target bacteria from the model foods. It was determined that the concentration of the additive used was not significant $(\mathrm{p}<0.05)$. Of all the additives tested, Tween 80 at $0.01 \%$ was the only one that increased recoveries over the BPW for each food and both bacteria used (fig. 2). The average of all 18 results using Tween $800.01 \%$ was $11.22 \%$ above the control values. The $95 \%$ confidence interval was calculated to be $11.22 \% \pm 5.79 \%$, which is greater than zero at its lower bound.

Based on results obtained from the hot dog tests, it was determined that Tween 80 at $0.01 \%$, decanol at $0.001 \%$, and $\mathrm{NaPP}$ at $1 \%$ were the additives and concentrations that resulted in the highest recoveries (table 1). This was determined by subtracting the recovery percentage of each bacteria with no additive treatment (BPW alone) from the additive treatments. Positive values indicate that the treatment resulted in higher recovery than the control, while negative values indicate that the treatment did not result in higher recovery compared to the control. From the spinach tests, Tween 80 at $0.1 \%$, hexanol at $0.001 \%$, and $\mathrm{NaPP}$ at $0.01 \%$ were the additives and concentrations that resulted in the highest recoveries. Finally, from the milk experiment, Brij 35 at $1 \%$, hexanol at $0.001 \%$, and $\mathrm{NaPP}$ at $1 \%$ were the most successful additives and concentrations used. These were the additives and concentrations that were then tested in combination for each food matrix. 


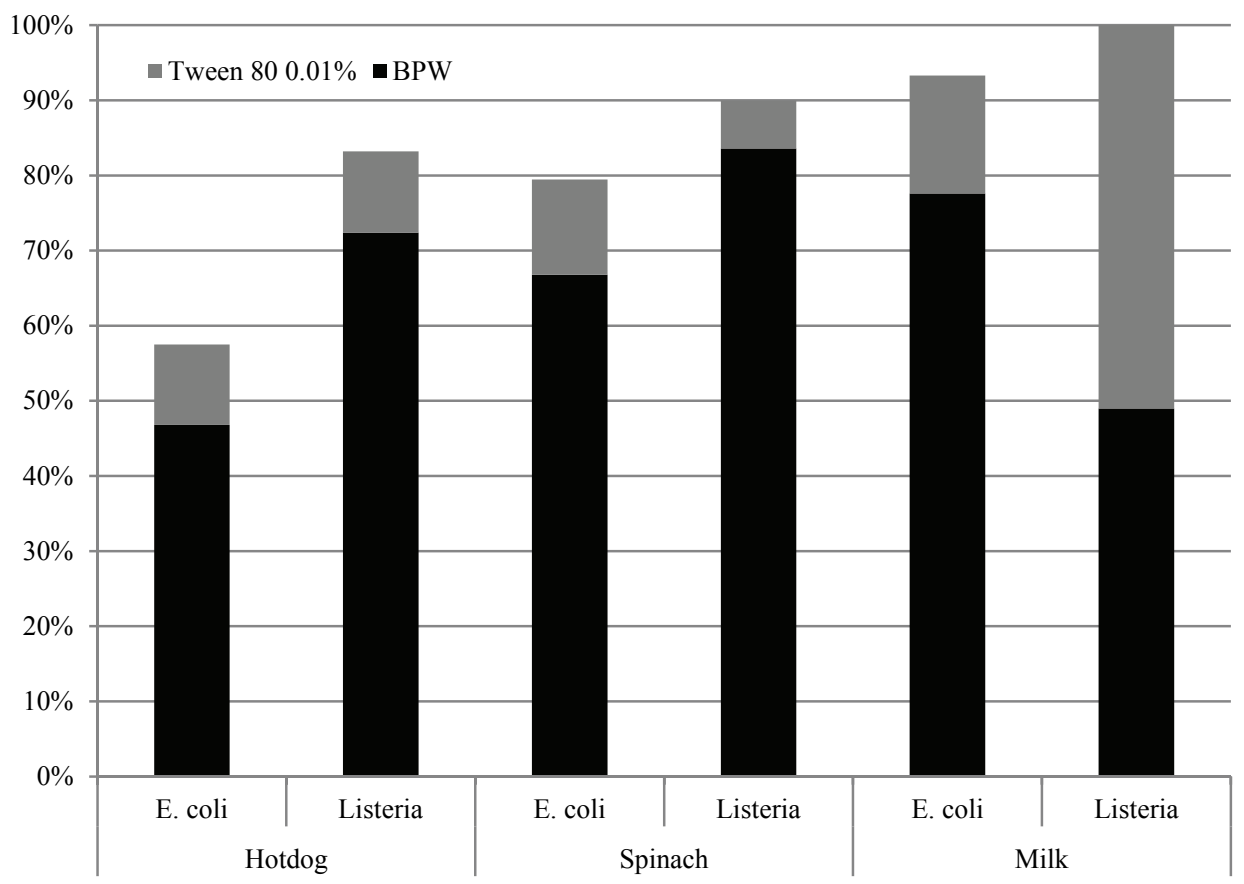

Figure 2. Microbial recovery with the use of BPW and the increase in recovery of target bacteria from the model foods with the use of Tween $800.01 \%$ for each food matrix tested.

Table 1. Recovery results $(n=3)$ normalized with control (treatment recovery $\%$ - control recovery \%). For hot dogs, $E$. coli control recovery averaged $47 \%$ and Listeria control recovery averaged $72 \%$. For spinach, $E$. coli control recovery averaged $67 \%$ and Listeria control recovery averaged $84 \%$. For milk, E. coli control recovery averaged $81 \%$ and Listeria control recovery averaged $59 \%$.

\begin{tabular}{|c|c|c|c|c|c|c|c|c|c|}
\hline \multirow{2}{*}{$\begin{array}{c}\text { Bacteria and } \\
\text { Additive }\end{array}$} & \multicolumn{3}{|c|}{ Hot Dogs } & \multicolumn{3}{|c|}{ Spinach } & \multicolumn{3}{|c|}{ Milk } \\
\hline & Low & Med. & High & Low & Med. & High & Low & Med. & High \\
\hline \multicolumn{10}{|l|}{ E. coli } \\
\hline Brij 35 & $6 \%$ & $4 \%$ & $-6 \%$ & $7 \%$ & $13 \%$ & $9 \%$ & $6 \%$ & $7 \%$ & $12 \%$ \\
\hline NP40 & $4 \%$ & $-11 \%$ & $6 \%$ & $-6 \%$ & $13 \%$ & $8 \%$ & $1 \%$ & $12 \%$ & $0 \%$ \\
\hline Tween 20 & $2 \%$ & $6 \%$ & $12 \%$ & $-8 \%$ & $-4 \%$ & $3 \%$ & $1 \%$ & $10 \%$ & $11 \%$ \\
\hline Tween 80 & $11 \%$ & $-8 \%$ & $-7 \%$ & $13 \%$ & $9 \%$ & $3 \%$ & $4 \%$ & $-1 \%$ & $-2 \%$ \\
\hline Decanol & $10 \%$ & $13 \%$ & $4 \%$ & $-4 \%$ & $-7 \%$ & $3 \%$ & $3 \%$ & $-2 \%$ & $15 \%$ \\
\hline Hexanol & $4 \%$ & $1 \%$ & $4 \%$ & $3 \%$ & $1 \%$ & $-67 \%$ & $17 \%$ & $10 \%$ & $8 \%$ \\
\hline $\mathrm{NaPP}$ & $12 \%$ & $7 \%$ & $12 \%$ & $12 \%$ & $3 \%$ & $-2 \%$ & $3 \%$ & $5 \%$ & $8 \%$ \\
\hline \multicolumn{10}{|l|}{ L. innocua } \\
\hline Brij 35 & $-8 \%$ & $-13 \%$ & $-12 \%$ & $0 \%$ & $-2 \%$ & $-10 \%$ & $11 \%$ & $-1 \%$ & $20 \%$ \\
\hline NP40 & $-12 \%$ & $-22 \%$ & $7 \%$ & $-2 \%$ & $-9 \%$ & $0 \%$ & $-7 \%$ & $5 \%$ & $2 \%$ \\
\hline Tween 20 & $-10 \%$ & $-3 \%$ & $-4 \%$ & $-20 \%$ & $-15 \%$ & $-8 \%$ & $23 \%$ & $20 \%$ & $14 \%$ \\
\hline Tween 80 & $10 \%$ & $-16 \%$ & $-10 \%$ & $6 \%$ & $18 \%$ & $-9 \%$ & $16 \%$ & $1 \%$ & $31 \%$ \\
\hline Decanol & $13 \%$ & $6 \%$ & $-20 \%$ & $-18 \%$ & $-8 \%$ & $-79 \%$ & $5 \%$ & $9 \%$ & $13 \%$ \\
\hline Hexanol & $0 \%$ & $6 \%$ & $-3 \%$ & $-16 \%$ & $-20 \%$ & $-84 \%$ & $15 \%$ & $17 \%$ & $11 \%$ \\
\hline $\mathrm{NaPP}$ & $-8 \%$ & $-9 \%$ & $0 \%$ & $1 \%$ & $-12 \%$ & $-7 \%$ & $7 \%$ & $13 \%$ & $41 \%$ \\
\hline
\end{tabular}

\section{Fatty Alcohols}

The use of both decanol and hexanol as additives for microbial separation has not been documented in the published literature. Decanol and hexanol were both tested in hot 
Table 2. Recovery data $\left(\mathrm{CFU} \mathrm{mL^{-1 }}\right)$ from the use of decanol and hexanol in each food matrix. ${ }^{\text {[a] }}$

\begin{tabular}{|c|c|c|c|c|c|c|c|c|c|c|c|c|c|}
\hline \multirow{2}{*}{$\begin{array}{c}\text { Bacteria and } \\
\text { Additive }\end{array}$} & \multirow[b]{2}{*}{ Conc } & \multicolumn{4}{|c|}{ Hot Dogs } & \multicolumn{4}{|c|}{ Spinach } & \multicolumn{4}{|c|}{ Milk } \\
\hline & & Inoc & Rec & $\mathrm{SD}$ & $\operatorname{Rec} \%$ & Inoc & $\operatorname{Rec}$ & $\mathrm{SD}$ & $\mathrm{Rec} \%$ & Inoc & $\mathrm{Rec}$ & $\mathrm{SD}$ & $\operatorname{Rec} \%$ \\
\hline \multicolumn{14}{|l|}{ E. coli } \\
\hline \multirow{3}{*}{ Decanol } & $0.001 \%$ & 6.20 & 5.99 & 0.27 & $61.5 \%$ & 6.29 & 6.05 & 0.20 & $57.7 \%$ & 5.83 & 5.77 & 0.10 & $86.4 \%$ \\
\hline & $0.01 \%$ & 6.21 & 5.99 & 0.16 & $60.7 \%$ & 6.28 & 6.04 & 0.15 & $57.2 \%$ & 5.83 & 5.79 & 0.14 & $89.6 \%$ \\
\hline & $0.10 \%$ & 6.37 & 6.06 & 0.07 & $49.3 \%$ & 6.28 & 6.12 & 0.06 & $69.5 \%$ & 5.88 & 5.86 & 0.01 & $95.5 \%$ \\
\hline \multirow{3}{*}{ Hexanol } & $0.001 \%$ & 6.39 & 6.13 & 0.06 & $55.2 \%$ & 6.36 & 6.20 & 0.04 & $68.8 \%$ & 5.88 & 5.88 & 0.04 & $98.2 \%$ \\
\hline & $0.01 \%$ & 6.27 & 5.95 & 0.10 & $48.0 \%$ & 6.35 & 6.19 & 0.05 & $68.7 \%$ & 5.88 & 5.84 & 0.06 & $90.4 \%$ \\
\hline & $0.10 \%$ & 6.23 & 5.94 & 0.03 & $51.4 \%$ & 6.32 & [b] & - & - & 5.88 & 5.83 & 0.02 & $89.1 \%$ \\
\hline \multicolumn{14}{|l|}{ L. innocua } \\
\hline \multirow{3}{*}{ Decanol } & $0.001 \%$ & 6.32 & 6.25 & 0.13 & $85.4 \%$ & 6.26 & 6.15 & 0.09 & $77.8 \%$ & 5.59 & 5.42 & 0.05 & $67.6 \%$ \\
\hline & $0.01 \%$ & 6.33 & 6.23 & 0.11 & $78.6 \%$ & 6.25 & 5.83 & 0.49 & $38.5 \%$ & 5.59 & 5.42 & 0.10 & $68.5 \%$ \\
\hline & $0.10 \%$ & 6.11 & 5.82 & 0.09 & $51.4 \%$ & 6.16 & 5.01 & 0.21 & 7.0 & 5.61 & 5.46 & 0.08 & $70.8 \%$ \\
\hline \multirow{3}{*}{ Hexanol } & $0.001 \%$ & 6.19 & 6.05 & 0.10 & $72.6 \%$ & 6.22 & 6.08 & 0.01 & $72.3 \%$ & 5.61 & 5.48 & 0.08 & $73.0 \%$ \\
\hline & $0.01 \%$ & 6.20 & 6.09 & 0.30 & $79.0 \%$ & 6.16 & 6.16 & 0.00 & $100.9 \%$ & 5.54 & 5.41 & 0.14 & $74.0 \%$ \\
\hline & $0.10 \%$ & 6.25 & 6.09 & 0.16 & $69.5 \%$ & 6.27 & - $[\mathrm{b}]$ & - & - & 5.54 & 5.37 & 0.02 & $68.6 \%$ \\
\hline
\end{tabular}

dogs, spinach, and whole milk and were found to aid recovery efficiencies in all three foods for both $E$. coli and L. innocua. However, at the highest concentration tested $(0.1 \%)$, the use of a fatty alcohol in the buffer solution for spinach samples resulted in significantly lower recovery of target bacteria from the model foods based on the resulting plate counts at the $10^{-3}$ dilution. Spinach is a non-fatty food, and it could be that fat can serve as a buffer for microorganisms. In the absence of fat, it could be that the alcohols had a lethal effect on the bacteria, or they could have injured the bacteria so that they would not grow on selective media. More research is needed to determine the reason for the significant effect that the higher concentration had on recovery percentages. Results can be found in table 2 .

\section{Additive Combinations}

The means of bacterial recovery from the use of additives and additive combinations in hot dog, spinach, and milk samples were not significantly different from one another $(\mathrm{p}=0.9995$ and $\mathrm{p}=0.9865$, respectively). The use of chemical additives in hot dog samples did not improve recovery of $E$. coli, but the recovery of $L$. innocua increased from the use of Tween 80, decanol, Tween $80+\mathrm{NaPP}$, decanol $+\mathrm{NaPP}$, and Tween $80+$ decanol + NaPP (table 3). In spinach samples, a visible numerical increase over the BPW treatment in recovery of both E. coli and L. innocua was seen with the combination of Tween $80+$ hexanol, Tween $80+\mathrm{NaPP}$, hexanol $+\mathrm{NaPP}$, and Tween $80+$ hexanol + $\mathrm{NaPP}$. Microbial recovery from milk samples was very high $(>93 \%)$ for each of the treatments examined.

The surfactant plus chemical dispersant and the surfactant plus fatty alcohol treatments resulted in high microbial recoveries in each of the foods examined. A different experimental procedure was implemented in order to look at a treatment of the two combinations of interest and compare them to a control (BPW with no additives). The goal of this updated experimental procedure was to be able to conduct the entire experiment in one day using the same batch of food, the same stock buffer solution with and without additives, and the same stock of bacteria to minimize potential sources of variability. The first such experiment tested Tween 80 at $0.01 \%$ and NaPP at $0.1 \%$ in 
Table 3. Average recovery rates $\left(\mathrm{CFU} \mathrm{mL}^{-1}\right)$ of inoculated food samples from different treatments alone and in combination $(n=4)$.

\begin{tabular}{|c|c|c|c|c|c|c|c|c|c|c|c|c|}
\hline \multirow{2}{*}{$\begin{array}{c}\text { Bacteria and } \\
\text { Treatments }\end{array}$} & \multicolumn{4}{|c|}{ Hot Dogs } & \multicolumn{4}{|c|}{ Spinach } & \multicolumn{4}{|c|}{ Milk } \\
\hline & Inoc & Rec & $\mathrm{SD}$ & $\operatorname{Rec} \%$ & Inoc & $\operatorname{Rec}$ & SD & $\operatorname{Rec} \%$ & Inoc & Rec & SD & $\operatorname{Rec} \%$ \\
\hline \multicolumn{13}{|l|}{ E. coli } \\
\hline BPW & 4.09 & 3.83 & 0.03 & $55.0 \%$ & 4.08 & 3.98 & 0.12 & $79.4 \%$ & 3.9 & 3.96 & 0.13 & $114.8 \%$ \\
\hline Surfactant & 4.09 & 3.7 & 0.04 & $40.7 \%$ & 4.08 & 4.01 & 0.12 & $85.1 \%$ & 3.9 & 3.94 & 0.21 & $109.7 \%$ \\
\hline Fatty alcohol (FA) & 4.09 & 3.78 & 0.12 & $49.0 \%$ & 4.08 & 3.98 & 0.07 & $79.4 \%$ & 3.9 & 3.93 & 0.24 & $107.2 \%$ \\
\hline $\mathrm{NaPP}$ & 4.09 & 3.73 & 0.08 & $43.7 \%$ & 4.08 & 3.93 & 0.13 & $70.8 \%$ & 3.9 & 3.94 & 0.2 & $110.0 \%$ \\
\hline Surfactant + FA & 4.09 & 3.63 & 0.13 & $34.7 \%$ & 4.08 & 4.05 & 0.11 & $93.3 \%$ & 3.9 & 3.93 & 0.22 & $107.2 \%$ \\
\hline Surfactant $+\mathrm{NaPP}$ & 4.09 & 3.71 & 0.16 & $41.7 \%$ & 4.08 & 4.02 & 0.05 & $87.1 \%$ & 3.9 & 4.05 & 0.06 & $141.3 \%$ \\
\hline $\mathrm{FA}+\mathrm{NaPP}$ & 4.09 & 3.77 & 0.15 & $47.9 \%$ & 4.08 & 4 & 0.1 & $83.2 \%$ & 3.9 & 3.91 & 0.18 & $102.3 \%$ \\
\hline $\begin{array}{l}\text { Surfactant + FA } \\
+\mathrm{NaPP}\end{array}$ & 4.09 & 3.72 & 0.1 & $42.7 \%$ & 4.08 & 4.02 & 0.1 & $87.1 \%$ & 3.9 & 3.87 & 0.25 & $93.3 \%$ \\
\hline \multicolumn{13}{|l|}{ L. innocua } \\
\hline BPW & 3.77 & 3.54 & 0.33 & $58.9 \%$ & 3.68 & 3.59 & 0.13 & $81.3 \%$ & 3.66 & 3.65 & 0.17 & $97.2 \%$ \\
\hline Surfactant & 3.77 & 3.59 & 0.22 & $66.1 \%$ & 3.68 & 3.58 & 0.09 & $79.4 \%$ & 3.66 & 3.64 & 0.21 & $95.5 \%$ \\
\hline Fatty alcohol (FA) & 3.77 & 3.56 & 0.27 & $61.7 \%$ & 3.68 & 3.63 & 0.13 & $89.1 \%$ & 3.66 & 3.64 & 0.21 & $95.5 \%$ \\
\hline $\mathrm{NaPP}$ & 3.77 & 3.5 & 0.33 & $53.7 \%$ & 3.68 & 3.66 & 0.14 & $95.5 \%$ & 3.66 & 3.65 & 0.26 & $97.7 \%$ \\
\hline Surfactant + FA & 3.77 & 3.44 & 0.27 & $46.8 \%$ & 3.68 & 3.61 & 0.17 & $85.1 \%$ & 3.66 & 3.65 & 0.22 & $97.7 \%$ \\
\hline Surfactant $+\mathrm{NaPP}$ & 3.77 & 3.56 & 0.26 & $61.7 \%$ & 3.68 & 3.62 & 0.18 & $87.1 \%$ & 3.66 & 3.76 & 0.13 & $125.9 \%$ \\
\hline $\mathrm{FA}+\mathrm{NaPP}$ & 3.77 & 3.61 & 0.18 & $69.2 \%$ & 3.68 & 3.64 & 0.13 & $91.2 \%$ & 3.66 & 3.68 & 0.22 & $104.7 \%$ \\
\hline $\begin{array}{l}\text { Surfactant + FA } \\
+\mathrm{NaPP}\end{array}$ & 3.77 & 3.57 & 0.24 & $63.1 \%$ & 3.68 & 3.6 & 0.13 & $83.2 \%$ & 3.66 & 3.63 & 0.25 & $93.3 \%$ \\
\hline
\end{tabular}

combination versus BPW with no additives for all three foods. The second experiment tested Tween 80 at $0.01 \%$ and hexanol at $0.001 \%$. Results can be found in tables 4 and 5 .

The addition of Tween 80 and NaPP to BPW increased recovery efficiencies from all food matrices and bacteria compared to BPW alone, except for $E$. coli from hot dogs $(75.9 \%$ vs. $93.3 \%)$. In some cases, the recovery percentage was greater than $100 \%$. This is most likely due to the inherent error that results from microbiological testing (Heller, 2004). It was noted that the standard deviation of recovered bacteria from the updated experimental procedure was smaller than with the other experiments.

Tween 80 plus hexanol was found to be the most successful combination of additives tested. Compared to BPW, the use of these two additives in buffer raised the bacterial recovery for both E. coli and L. innocua from the three foods tested.

Table 4. Average recovery rates $\left(\mathrm{CFU} \mathrm{mL}^{-1}\right)$ of inoculated food samples by using Tween $80(0.01 \%)$ and NaPP $(0.1 \%)$ versus BPW.

\begin{tabular}{|c|c|c|c|c|c|c|}
\hline Food & Bacteria & Treatment & Inoculum & Recovered & $\begin{array}{c}\text { SD } \\
\text { (Recovered) }\end{array}$ & $\begin{array}{l}\text { Percent } \\
\text { Recovery }\end{array}$ \\
\hline \multirow{4}{*}{ Hot dogs } & \multirow{2}{*}{ E. coli } & BPW & 3.83 & 3.80 & 0.00 & $93.3 \%$ \\
\hline & & Additives & 3.83 & 3.71 & 0.02 & $75.9 \%$ \\
\hline & \multirow{2}{*}{ L. innocua } & BPW & 3.75 & 3.47 & 0.06 & $52.5 \%$ \\
\hline & & Additives & 3.75 & 3.52 & 0.06 & $58.9 \%$ \\
\hline \multirow{4}{*}{ Spinach } & \multirow{2}{*}{ E. coli } & BPW & 3.91 & 3.83 & 0.07 & $83.2 \%$ \\
\hline & & Additives & 3.91 & 3.90 & 0.06 & $97.7 \%$ \\
\hline & \multirow{2}{*}{ L. innocua } & BPW & 3.75 & 3.76 & 0.08 & $102.3 \%$ \\
\hline & & Additives & 3.75 & 3.78 & 0.11 & $107.2 \%$ \\
\hline \multirow{4}{*}{ Milk } & \multirow{2}{*}{ E. coli } & BPW & 3.92 & 3.89 & 0.02 & $93.3 \%$ \\
\hline & & Additives & 3.92 & 3.93 & 0.03 & $102.3 \%$ \\
\hline & \multirow{2}{*}{ L. innocua } & BPW & 3.75 & 3.73 & 0.03 & $95.5 \%$ \\
\hline & & Additives & 3.75 & 3.74 & 0.06 & $97.7 \%$ \\
\hline
\end{tabular}


Table 5. Average recovery rates of inoculated food samples by using Tween $80(0.01 \%)$ and hexanol (0.001\%) versus BPW.

\begin{tabular}{|c|c|c|c|c|c|c|}
\hline Food & Bacteria & Treatment & Inoculum & Recovered & $\begin{array}{c}\text { SD } \\
\text { (Recovered) }\end{array}$ & $\begin{array}{c}\text { Percent } \\
\text { Recovery }\end{array}$ \\
\hline \multirow{4}{*}{ Hot dogs } & \multirow{2}{*}{ E. coli } & Control & 3.84 & 3.56 & 0.08 & $52.5 \%$ \\
\hline & & Additives & 3.84 & 3.58 & 0.06 & $55.0 \%$ \\
\hline & \multirow{2}{*}{ L. innocua } & Control & 3.69 & 3.58 & 0.07 & $77.6 \%$ \\
\hline & & Additives & 3.69 & 3.63 & 0.04 & $87.1 \%$ \\
\hline \multirow{4}{*}{ Spinach } & \multirow{2}{*}{ E. coli } & Control & 3.84 & 3.64 & 0.02 & $63.1 \%$ \\
\hline & & Additives & 3.84 & 3.68 & 0.05 & $69.2 \%$ \\
\hline & \multirow{2}{*}{ L. inпосиа } & Control & 3.69 & 3.64 & 0.04 & $89.1 \%$ \\
\hline & & Additives & 3.69 & 3.67 & 0.04 & $95.5 \%$ \\
\hline \multirow{4}{*}{ Milk } & \multirow{2}{*}{ E. coli } & Control & 3.84 & 3.76 & 0.02 & $83.2 \%$ \\
\hline & & Additives & 3.84 & 3.76 & 0.03 & $83.2 \%$ \\
\hline & \multirow{2}{*}{ L. innocua } & Control & 3.69 & 3.54 & 0.04 & $70.8 \%$ \\
\hline & & Additives & 3.69 & 3.56 & 0.05 & $74.1 \%$ \\
\hline
\end{tabular}

\section{Conclusions}

Chemical additives were assessed for their efficacy in the separation and recovery of bacteria inoculated on three target foods: hot dogs, spinach, and milk. Of the additives tested, the surfactant Tween 80 was the most effective for the recovery of both E. coli and L. innocua. Fatty alcohols (decanol and hexanol) were found to be effective for separation. However, at a concentration of $0.1 \%$, they significantly lowered the bacterial recovery from spinach samples. The most effective concentration was found to be $0.001 \%$. The chemical dispersant NaPP was found to be effective at aiding in microbial recovery at each concentration tested.

Various combinations of additives were tested to determine if there was a synergistic effect of using more than one additive in BPW. The results varied, but one combination was found that resulted in higher recoveries compared to the BPW for all trials conducted: Tween $80(0.01 \%)$ and hexanol $(0.001 \%)$, the surfactant and fatty alcohol combination.

In conclusion, certain chemical additives were found to improve microbial recovery; however, the microbial extraction enhancement from the use of chemical additives was not uniformly measured in different food matrices. The goal of this research was to provide data supporting the use of chemical additives not previously researched for use in food testing and to compare them to commonly used surfactants (i.e., Tween 20 and Tween 80). Based on the results, further studies should be conducted using fatty alcohols and chemical dispersants. In certain cases, it was unclear how good or poor bacterial attachment was to each of the food matrices. In addition, recovery was measured using selective plate counts for both E. coli and L. innocua. Future research should incorporate the use of rapid detection methods, such as PCR or FTIR, to determine whether or not the use of these chemical additives poses any limitations to their use.

\section{Acknowledgements}

Research supported by funding from the U.S. Department of Homeland Security, Science and Technology Directorate, through the National Institute for Hometown Security. The information reported in this article (No. 13-05-075) is part of a project of the Kentucky Agricultural Experiment Station and is published with the approval of the Director. A special thanks to Heejeong Son for her invaluable help in the lab. 


\section{References}

Brehm-Stecher, B., C. Young, L. A. Jaykus, and M. L. Tortorello. 2009. Sample preparation: The forgotten beginning. J. Food Prot. 72(8): 1774-1789.

Brown, D. G., and P. R. Jaffé. 2001. Effects of nonionic surfactants on bacterial transport through porous media. Environ. Sci. Tech. 35(19): 3877-3883.

Butler, J. L., J. C. Steward, C. Vanderzant, Z. L. Carpenter, and G. C. Smith. 1979. Attachment of microorganisms to pork skin and surfaces of beef and lamb carcasses. J. Food Prot. 42: 401-406.

Fukushima, H., K. Katsube, Y. Hata, R. Kishi, and S. Fujiwara. 2007. Rapid separation and concentration of foodborne pathogens in food samples prior to quantification by viable cell counting and real-time PCR. Appl. Environ. Microbiol. 73(1): 92-100.

Garcia, J. M., L. Y. Wick, and H. Harms. 2001. Influence of the nonionic surfactant Brij 35 on the bioavailability of solid and sorbed dibenzofuran. Environ. Sci. Tech. 35(10): 2033-2039.

Hamilton-Kemp, T., M. Newman, R. Collins, H. Elgaali, K. Yu, and D. Archbold. 2005. Production of the long-chain alcohols octanol, decanol, and dodecanol by Escherichia coli. Current Microbiol. 51(2): 282-286.

Heller, K. 2004. Dairy Microbiology Handbook: The Microbiology of Milk and Milk Products. 3rd ed. R. K. Robinson, ed. John Wiley and Sons.

Hill, V. R., A. L. Polaczyk, D. Hahn, J. Narayanan, T. L. Cromeans, J. M. Roberts, and J. E. Amburgey. 2005. Development of a rapid method for simultaneous recovery of diverse microbes in drinking water by ultrafiltration with sodium polyphosphate and surfactants. Appl. Environ. Microbiol. 71(11): 6878-6884.

Lukasik, J., M. L. Bradley, W. Hsu, T. M. Scott, S. R. Farrah, and M. Tamplin. 2001. Elution, detection, and quantification of polio 1, bacteriophages, Salmonella Montevideo, and E. coli 0157:H7 from seeded strawberries and tomatoes. J. Food Prot. 64(2): 618-62.

Mandal, P. K., A. K. Biswas, K. Choi, and U. K. Pal. 2010. Methods for rapid detection of foodborne pathogens: An overview. American J. Food Tech. 6(2): 87-102.

Materon, L. A. 2003. Survival of Escherichia coli O157:H7 applied to cantaloupes and the effectiveness of chlorinated water and lactic acid as disinfectants. World J. Microbiol. Biotech. 19(8): 867-873.

Miller, N. D., P. M. Davidson, and D. H. D’Souza. 2011. Real-time reverse-transcriptase PCR for Salmonella typhimurium detection from lettuce and tomatoes. LWT - Food Sci. and Tech 44(4): 1088-1097.

Mudge, S. M., W. Meier-Augenstein, C. Eadsforth, and P. DeLeo. 2010. What contribution do detergent fatty alcohols make to sewage discharges and the marine environment? J. Environ. Monit. 12(10): 1846-1856.

Neumann, G., S. Cornelissen, and F. van Breukelen. 2006. Energetics and surface properties of Pseudomonas putida DOT-T1E in a two-phase fermentation system with 1-decanol as second phase. Appl. Environ. Microbiol. 72(6): 4232-4238.

Payne, M. J., and R. G. Kroll. 1991. Methods for the separation and concentration of bacteria from foods. Trends in Food Sci. and Tech. 2: 315-319.

Sharma, M. M., Y. I. Chang, and T. F. Yen. 1985. Reversible and irreversible surface charge modifications of bacteria for facilitating transport through porous media. Colloids Surf. 16(2): 193206.

Stevens, K. A., and L. A. Jaykus. 2004. Bacterial separation and concentration from complex sample matrices: A review. Crit. Rev. Microbiol. 30(1): 7-24.

Swaminathan, B. 1994. Rapid detection of foodborne pathogenic bacteria. Ann. Rev. Microbiol. 48 : 401-426.

Yuste, J., M. Capellas, D. Y. C. Fung, and M. Montserrat. 2004. Inactivation and sublethal injury of foodborne pathogens by high-pressure processing: Evaluation with conventional media and thin agar layer method. Food Res. Intl. 37(9): 861-866. 